
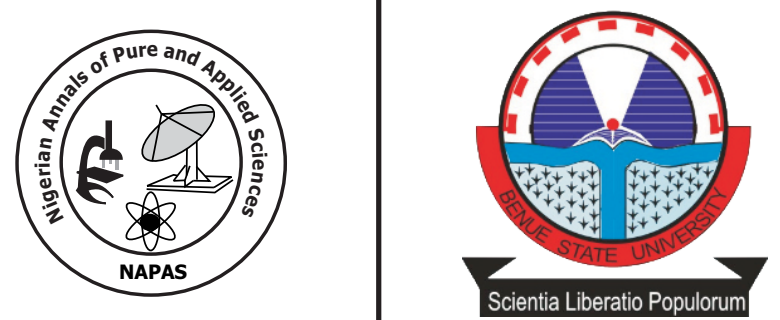

\title{
Assessment of levels of Heavy Metal Contents in Foods Sold to public in Benin City, Southern Nigeria
}

pp $67-74$

\author{
Enuneku, A. A. . ., Bamawo, R. E. ${ }^{2}$ \\ ${ }^{1}$ Department of Environmental Management and Toxicology, \\ Faculty of Life Sciences, University of Benin City, Nigeria. \\ ${ }^{2}$ Department of Animal and Environmental Biology, \\ University of Benin, PMB 1154, Benin City, Nigeria. \\ Email of corresponding author: alex.enuneku@uniben.edu
}

\begin{abstract}
Heavy metals contents $(\mathrm{Zn}, \mathrm{Cd}, \mathrm{Fe}$ and $\mathrm{Pb}$ ) were analyzed in canned foods frequently consumed in Benin City. Samples were collected from major supermarkets. These samples were categorized into 3 distinctive groups of 3 varying brands with triplicates each of fish, beans and vegetables (Peas, Carrots and Green Beans). The metals were analyzed using atomic absorption spectrophotometer (AAS). The results showed significant differences $(\mathrm{p}<0.05)$ in the values of $\mathrm{Cu}$ and $\mathrm{Fe}$ and a highly significant difference $(\mathrm{p}<0.001)$ in $\mathrm{Cd}$ in the different brands of canned fish samples. Iron Fe, was found to be prevalent in all classes of food tested with values as high as $20.57 \pm 1.14 \mathrm{mg} / \mathrm{l}$ in Peas (Del Monte). Concentrations of Fe in body tissues must be highly monitored because in excessive amounts, it can lead to tissue damage. Similarly, for all brands of canned foods examined, $\mathrm{Cd}$ had the lowest mean concentration $(0.01 \pm 0.00) \mathrm{mg} / \mathrm{kg}$ in all brands of canned fish. A regular monitoring of canned foods available to the public is recommended to safeguard public health especially when recommended levels are exceeded.
\end{abstract}

Key words: Canned Foods; Metals; Health; Monitoring. 


\section{Introduction}

Food contamination by chemical agents is a worldwide public health concern. The origins of chemical contaminants are multifarious from the field to the plate some of which include soil, environment, air, water, and packaging material (Rather et al., 2017). The constituent of food intake by human population has become a major concern in all parts of the world today. Elements present in the natural system have been categorized into those essential for human metabolism and the nonessential ones. Heavy metals are toxic in high amounts and pose serious effects on human populations due to frequent exposure (Dehelean and Magdas, 2013; Prashanth et al., 2015; Salma et al., 2015; Savić et al., 2015; Ghasemidehkordi et al., 2018).

The intake of food containing heavy metals can lead to several health challenges including nervous system breakdown, liver, lung and kidney damages due to chronic accumulation of these metals in tissues and blood (Makki and Ziarati, 2014; Mashhadizadeh et al., 2014; Ghasemidehkordi et al., 2018). The presence of heavy metals in canned foods is relatively higher as a result of natural contamination of the foodstuffs from soil and water, preparation, preservation or packaging through migration of toxic heavy metals from their metallic packaging materials (Blunden and Wallace, 2003; Kocak et al., 2005; Maduabuchi et al., 2007; Khalafalla et al., 2016). Metals toxicity has 2 major aspects: ability to alter metabolic functions and cellular activities and ability to bio-accumulate in tissues and organs (Liver and Kidney).

Fish, baked beans, tomatoes, carrots, green beans and peas which were studied in this research are consumed on a wide scale around the world including Nigeria because of their nutritional value in their ground state and increasing pressure to consume ready-made food due to job or office exigencies and schedules.

This research focuses on the level of heavy metals $(\mathrm{Zn}, \mathrm{Pb}, \mathrm{Cd}, \mathrm{Cr}$, and $\mathrm{Fe}$ ) in foods sold to the public in Benin City. This will provide current data on metal contamination of commonly sold public foods with a view for proactive actions on prevention and attenuation.

\section{Materials and Methods \\ Samples Collection}

All samples for this study were collected from major supermarkets in Benin City. This samples were categorized into 3 distinctive groups of 3 varying brands with triplicates each; Fish, Beans and Vegetables (Peas, Carrots and Green Beans), bringing the total of all samples examined to 54. The samples were properly tagged according to brands and categories in sterilized plastic and taken to the Laboratory for Ecotoxicology and Environmental Forensics, University of Benin for sorting and heavy metal analyses.

\section{Sample Preparation \\ Chemicals and reagents}

All chemicals and reagents were analytical grade. Materials and reagents were used including $72 \% \mathrm{HNO}_{3}(\mathrm{BDH}), 37 \% \mathrm{HCl}$ (JHD). In order to construct the calibration curves, working standard solutions for heavy metals were freshly prepared by diluting an appropriate aliquot of standard solutions containing $1000 \mathrm{ppm}$ with serial concentrations for each element using $0.1 \% \mathrm{HNO}_{3}$. Glassware and polyethylene containers were cleaned and soaked in $10 \% \mathrm{HNO}_{3}$ for 48 hours and then rinsed thoroughly with deionized water.

\section{Sample digestion and heavy metal analysis}

In the laboratory, the food samples were dried and grounded with ceramic mortar and pestle. Digestion of food samples was carried out after the modified method of Likuku et al., 2013 and Massadeh et al., 2017). Then $1 \mathrm{~g}$ of sample was digested in $10 \mathrm{ml}$ freshly prepared aqua regia $\left(3: 1, \mathrm{HNO}_{3}: \mathrm{HCl}\right)$ in a hot sand bath on a hot plate for 45 minutes. It was allowed to cool. Twenty (20) $\mathrm{ml}$ of distilled water was then added. Then it was filtered through a whatman filter paper $(110 \mathrm{~mm})$ into a $100 \mathrm{ml}$ standard flask. It was made up to mark with distilled water. Samples were then analysed for heavy metals using atomic absorption spectrophotometer (Buck Scientific, 210 VGP).

\section{Statistical Analyses}

Triplicates $(n=3)$ for all experiments were subjected to a one - way analysis of variance (ANOVA) and level of significances set at $\mathrm{P}<0.05$ probability. Data analysis was performed using SPSS version 23.0. 


\section{Results and Discussion}

The means and standard errors as well as minimum and maximum levels of heavy metals for different canned foods analyzed are shown tables $1-6$.

Table 1: Comparison of Heavy Metals Concentrations in different Brands of Canned Fish

\begin{tabular}{lccccc}
\hline $\begin{array}{l}\text { Elements } \\
(\mathrm{mg} / \mathrm{kg})\end{array}$ & Blue Pearl & Costa & Titus & \multirow{2}{*}{ F value } & P Value \\
\cline { 2 - 4 } & $\begin{array}{c}\text { Mean } \pm \text { SD } \\
(\text { Min }- \text { Max })\end{array}$ & $\begin{array}{c}\text { Mean } \pm \text { SD } \\
(\text { Min }- \text { Max })\end{array}$ & $\begin{array}{c}\text { Mean } \pm \text { SD } \\
(\text { Min }- \text { Max })\end{array}$ & & \\
\hline $\mathrm{Zn}$ & $0.18 \pm 0.11$ & $0.18 \pm 0.15$ & $0.39 \pm 0.03$ & 3.707 & $p>0.05$ \\
& $(0.08-0.30)$ & $(0.03-0.32)$ & $(0.37-0.43)$ & & \\
$\mathrm{Cd}$ & $0.01 \pm 0.00^{\mathrm{a}}$ & $0.01 \pm 0.00^{\mathrm{b}}$ & $0.01 \pm 0.00^{\mathrm{c}}$ & 67.400 & $p<0.001$ \\
& $(0.01-0.01)$ & $(0.01-0.01)$ & $(0.01-0.02)$ & & \\
$\mathrm{Cu}$ & $0.19 \pm 0.24^{\mathrm{a}}$ & $0.92 \pm 0.81^{\mathrm{a}}$ & $2.27 \pm 0.35^{\mathrm{b}}$ & 11.977 & $p<0.05$ \\
& $(0.03-0.47)$ & $(0.21-1.81)$ & $(1.87-2.53)$ & & \\
$\mathrm{Fe}$ & $6.89 \pm 1.06^{\mathrm{b}}$ & $10.46 \pm 0.59^{\mathrm{c}}$ & $2.57 \pm 1.94^{\mathrm{a}}$ & 26.809 & $p<0.05$ \\
& $(6.05-8.08)$ & $(9.84-11.01)$ & $(0.33-3.86)$ & & \\
$\mathrm{Pb}$ & $0.06 \pm 0.48$ & $0.07 \pm 0.01$ & $0.07 \pm 0.00$ & 0.030 & $p>0.05$ \\
& $(0.01-0.10)$ & $(0.06-0.07)$ & $(0.06-0.08)$ & & \\
\hline
\end{tabular}

$p<0.05$ significant difference; $p<0.001$ highly significant difference. Different superscript indicates homogenous subsets based on Duncan Multiple Range test.

Table 2: Comparison of Heavy Metal Concentrations in different Brand of Canned Baked Beans

\begin{tabular}{lccccc}
\hline $\begin{array}{l}\text { Elements } \\
(\mathrm{mg} / \mathrm{kg})\end{array}$ & Heinze & White Pearl & Gino baked & F value & P Value \\
\cline { 2 - 4 } & $\begin{array}{c}\text { Mean } \pm \text { SD } \\
(\text { Min }- \text { Max })\end{array}$ & $\begin{array}{c}\text { Mean } \pm \text { SD } \\
(\text { Min }- \text { Max })\end{array}$ & $\begin{array}{c}\text { Mean } \pm \text { SD } \\
(\text { Min }- \text { Max })\end{array}$ & & \\
\hline $\mathrm{Zn}$ & $0.41 \pm 0.03^{\mathrm{a}}$ & $0.59 \pm 0.04^{\mathrm{a}}$ & $0.93 \pm 0.21^{\mathrm{b}}$ & 14.028 & $p<0.05$ \\
& $(0.37-0.44)$ & $(0.54-0.62)$ & $(0.81-1.17)$ & & \\
$\mathrm{Cd}$ & $0.05 \pm 0.01$ & $0.04 \pm 0.01$ & $0.04 \pm 0.01$ & 2.945 & $p>0.05$ \\
& $(0.05-0.06)$ & $(0.03-0.06)$ & $(0.03-0.04)$ & & \\
$\mathrm{Cu}$ & $1.94 \pm 0.34$ & $1.97 \pm 0.84$ & $1.95 \pm 1.05$ & 0.002 & $p>0.05$ \\
& $(1.57-2.22)$ & $(1.03-2.64)$ & $(0.92-3.03)$ & & \\
$\mathrm{Fe}$ & $2.19 \pm 0.65^{\mathrm{a}}$ & $4.10 \pm 0.37^{\mathrm{b}}$ & $6.23 \pm 1.10^{\mathrm{c}}$ & 20.699 & $p<0.05$ \\
& $(1.61-2.90)$ & $(3.84-4.52)$ & $(4.99-7.06)$ & & \\
$\mathrm{Pb}$ & $0.06 \pm 0.01$ & $0.35 \pm 0.48$ & $0.06 \pm 0.02$ & 1.087 & $p>0.05$ \\
& $(0.05-0.07)$ & $(0.05-0.91)$ & $(0.05-0.08)$ & & \\
\hline
\end{tabular}

$p<0.05$ significant difference; $p<0.001$ highly significant difference. Different superscript indicates homogenous subsets based on Duncan Multiple Range test. 
70 | Assessment of levels of Heavy Metal Contents in Foods Sold to public in Benin City, Southern Nigeria

Table 3: Comparison of Heavy Metal Concentrations in Canned Tomatoes

\begin{tabular}{lccccc}
\hline Elements & Clappa & Lena & Gino & \multirow{2}{*}{ F value } & P Value \\
\cline { 2 - 4 }$(\mathrm{mg} / \mathrm{kg})$ & $\begin{array}{c}\text { Mean } \pm \text { SD } \\
(\text { Min }- \text { Max })\end{array}$ & $\begin{array}{c}\text { Mean } \pm \text { SD } \\
(\text { Min }- \text { Max })\end{array}$ & $\begin{array}{c}\text { Mean } \pm \text { SD } \\
(\text { Min }- \text { Max })\end{array}$ & & \\
\hline $\mathrm{Zn}$ & $0.81 \pm 0.70$ & $1.10 \pm 0.07$ & $1.47 \pm 0.20$ & 1.886 & $p>0.05$ \\
& $(0.00-1.21)$ & $(1.04-1.18)$ & $(1.35-1.70)$ & & \\
$\mathrm{Cd}$ & $0.04 \pm 0.01^{\mathrm{a}}$ & $0.07 \pm 0.03^{\mathrm{b}}$ & $0.07 \pm 0.01^{\mathrm{b}}$ & \multirow{2}{*}{4.737} & $p>0.05$ \\
& $(0.03-0.04)$ & $(0.05-0.10)$ & $(0.06-0.08)$ & & \\
$\mathrm{Cu}$ & $1.93 \pm 0.57$ & $2.89 \pm 0.06$ & $2.42 \pm 0.54$ & 3.319 & $p>0.05$ \\
& $(1.40-2.53)$ & $(2.85-2.96)$ & $(1.81-2.84)$ & & \\
$\mathrm{Fe}$ & $8.66 \pm 0.71^{\mathrm{b}}$ & $0.75 \pm 0.19^{\mathrm{a}}$ & $11.01 \pm 5.38^{\mathrm{b}}$ & 8.834 & $p<0.05$ \\
& $(7.84-9.17)$ & $(0.53-0.87)$ & $(6.85-17.09)$ & & \\
$\mathrm{Pb}$ & $0.17 \pm 0.21$ & $0.12 \pm 0.08$ & $0.08 \pm 0.05$ & 0.324 & $p>0.05$ \\
& $(0.04-0.42)$ & $(0.03-0.18)$ & $(0.05-0.14)$ & & \\
\hline
\end{tabular}

$p<0.05$ significant difference; $p<0.001$ highly significant difference. Different superscript indicates homogenous subsets based on Duncan Multiple Range test

Table 4: Comparison of Heavy Metal Concentrations in Canned Carrots

\begin{tabular}{lccccc}
\hline \multirow{2}{*}{$\begin{array}{l}\text { Elements } \\
(\mathrm{mg} / \mathrm{kg})\end{array}$} & Trio & Del Monte & Green giant & F value & P Value \\
\cline { 2 - 4 } & $\begin{array}{c}\text { Mean } \pm \text { SD } \\
(\text { Min }- \text { Max })\end{array}$ & $\begin{array}{c}\text { Mean } \pm \text { SD } \\
(\text { Min }- \text { Max })\end{array}$ & $\begin{array}{c}\text { Mean } \pm \text { SD } \\
(\text { Min }- \text { Max })\end{array}$ & & \\
\hline $\mathrm{Zn}$ & $1.68 \pm 0.16^{\mathrm{a}}$ & $1.68 \pm 0.16^{\mathrm{a}}$ & $2.73 \pm 0.69^{\mathrm{b}}$ & 6.254 & $p<0.05$ \\
& $(1.55-1.86)$ & $(1.55-1.86)$ & $(2.07-3.45)$ & & \\
$\mathrm{Cd}$ & $0.07 \pm 0.12$ & $0.21 \pm 0.23$ & $0.02 \pm 0.00$ & 1.588 & $p>0.05$ \\
& $(0.05-0.08)$ & $(0.07-0.47)$ & $(0.02-0.03)$ & & \\
$\mathrm{Cu}$ & $2.30 \pm 0.21$ & $2.30 \pm 0.21$ & $2.33 \pm 0.18$ & 0.025 & $p>0.05$ \\
& $(2.15-2.54)$ & $(2.15-2.54)$ & $(2.14-2.49)$ & & \\
$\mathrm{Fe}$ & $14.36 \pm 0.26^{\mathrm{b}}$ & $14.36 \pm 0.26^{\mathrm{b}}$ & $11.13 \pm 0.52^{\mathrm{a}}$ & 76.741 & $p<0.001$ \\
& $(14.18-$ & $(14.18-$ & $(10.57-$ & & \\
$\mathrm{Pb}$ & $14.66)$ & $14.66)$ & $11.61)$ & & \\
& $0.06 \pm 0.01$ & $0.06 \pm 0.01$ & $0.04 \pm 0.00$ & 2.334 & $p>0.05$ \\
\hline
\end{tabular}

$p<0.05$ significant difference; $p<0.001$ highly significant difference. Different superscript indicates homogenous subsets based on Duncan Multiple Range test. 
Table 5: Comparison of Heavy Metal Concentration in Green Beans

\begin{tabular}{lccccc}
\hline \multirow{2}{*}{$\begin{array}{l}\text { Elements } \\
(\mathrm{mg} / \mathrm{kg})\end{array}$} & Trio green & Del Monte & Green giant & \multirow{2}{*}{ F value } & P Value \\
\cline { 2 - 4 } & $\begin{array}{c}\text { Mean } \pm \text { SD } \\
(\text { Min }- \text { Max })\end{array}$ & $\begin{array}{c}\text { Mean } \pm \text { SD } \\
(\text { Min }- \text { Max })\end{array}$ & $\begin{array}{c}\text { Mean } \pm \text { SD } \\
(\text { Min }- \text { Max })\end{array}$ & & \\
\hline $\mathrm{Zn}$ & $4.17 \pm 0.69^{\mathrm{a}}$ & $1.74 \pm 0.16^{\mathrm{a}}$ & $2.90 \pm 1.18^{\mathrm{a}}$ & 11.99 & $p<0.05$ \\
& $(3.72-4.97)$ & $(1.65-1.92)$ & $(2.04-3.54)$ & & \\
$\mathrm{Cd}$ & $0.02 \pm 0.02^{\mathrm{a}}$ & $0.09 \pm 0.01^{\mathrm{b}}$ & $0.03 \pm 0.00^{\mathrm{a}}$ & 31.287 & $p<0.05$ \\
& $(0.00-0.04)$ & $(0.09-0.10)$ & $(0.02-0.03)$ & & \\
$\mathrm{Cu}$ & $4.29 \pm 0.57^{\mathrm{b}}$ & $1.63 \pm 1.11^{\mathrm{a}}$ & $4.34 \pm 0.27^{\mathrm{b}}$ & 13.397 & $p<0.05$ \\
& $(3.75-4.89)$ & $(0.58-2.79)$ & $(4.12-4.63)$ & & \\
$\mathrm{Fe}$ & $18.40 \pm 0.37^{\mathrm{b}}$ & $18.40 \pm 0.48^{\mathrm{b}}$ & $15.15 \pm 1.67^{\mathrm{a}}$ & 10.059 & $p<0.05$ \\
& $(18.00-18.73)$ & $(17.90-$ & $(13.65-$ & & \\
$\mathrm{Pb}$ & $0.06 \pm 0.01$ & $0.06 \pm 0.01$ & $0.04 \pm 0.01$ & 2.495 & $p>0.05$ \\
& $(0.05-0.07)$ & $(0.06-0.07)$ & $(0.03-0.05)$ & & \\
\hline
\end{tabular}

$p<0.05$ significant difference; $p<0.001$ highly significant difference. Different superscript indicates homogenous subsets based on Duncan Multiple Range test

Table 6: Comparison of Heavy Metal Concentration in Peas

\begin{tabular}{lccccc}
\hline \multirow{2}{*}{$\begin{array}{l}\text { Elements } \\
(\mathrm{mg} / \mathrm{kg})\end{array}$} & Trio peas & Del Monte & Green giant & \multirow{2}{*}{ F value } & P Value \\
\cline { 2 - 4 } & $\begin{array}{c}\text { Mean } \pm \text { SD } \\
(\text { Min }- \text { Max })\end{array}$ & $\begin{array}{c}\text { Mean } \pm \text { SD } \\
(\text { Min }- \text { Max })\end{array}$ & $\begin{array}{c}\text { Mean } \pm \text { SD } \\
(\text { Min }- \text { Max })\end{array}$ & & \\
\hline $\mathrm{Zn}$ & $1.11 \pm 0.10^{\mathrm{a}}$ & $2.50 \pm 0.80^{\mathrm{a}}$ & $3.18 \pm 1.32^{\mathrm{b}}$ & 4.198 & $p>0.05)$ \\
& $(1.05-1.23)$ & $(1.94-3.41)$ & $(2.06-4.64)$ & & \\
$\mathrm{Cd}$ & $0.03 \pm 0.00^{\mathrm{a}}$ & $0.11 \pm 0.02^{\mathrm{b}}$ & $0.05 \pm 0.01^{\mathrm{a}}$ & 34.087 & $p<0.05$ \\
& $(0.03-0.04)$ & $(0.09-0.12)$ & $(0.04-0.05)$ & & \\
$\mathrm{Cu}$ & $3.07 \pm 0.19^{\mathrm{b}}$ & $1.88 \pm 0.20^{\mathrm{a}}$ & $4.87 \pm 0.42^{\mathrm{c}}$ & 81.111 & $p<0.001$ \\
& $(2.89-3.26)$ & $(1.71-2.10)$ & $(4.39-5.12)$ & & \\
$\mathrm{Fe}$ & $9.80 \pm 1.51^{\mathrm{a}}$ & $20.57 \pm 1.14^{\mathrm{b}}$ & $19.73 \pm 1.65^{\mathrm{b}}$ & 51.263 & $p<0.001$ \\
& $(8.15-11.12)$ & $(19.82-$ & $(18.63-$ & & \\
& & $21.88)$ & $21.63)$ & & \\
$\mathrm{Pb}$ & $0.05 \pm 0.01$ & $0.32 \pm 0.36$ & $0.06 \pm 0.002$ & 1.638 & $p>0.05$ \\
& $(0.04-0.06)$ & $(0.06-0.73)$ & $(0.04-0.07)$ & & \\
\hline
\end{tabular}

$p<0.05$ significant difference; $p<0.001$ highly significant difference. Different superscript indicates homogenous subsets based on Duncan Multiple Range test.

In all foods studied, the highest mean concentration $(4.17 \pm 0.69 \mathrm{mg} / \mathrm{kg})$ of $\mathrm{Zn}$ occurred in green beans (Trio Green), while the lowest mean concentration $(0.39 \pm 0.03 \mathrm{mg} / \mathrm{kg})$ occurred in canned fish (Titus). The highest mean concentration $(0.11 \pm 0.02 \mathrm{mg} / \mathrm{kg})$ of $\mathrm{Cd}$ occurred in peas (De Monte), while the lowest mean concentration $(0.01 \pm 0.00 \mathrm{mg} / \mathrm{kg})$ occurred in all brands of fish. The highest mean concentration $(4.87 \pm 0.42 \mathrm{mg} / \mathrm{kg})$ of $\mathrm{Cu}$ occurred in peas (Green Giant) while the lowest mean concentration $(0.19 \pm 0.24 \mathrm{mg} / \mathrm{kg})$ occurred in fish (Blue Pearl). The highest mean concentration $(20.57 \pm 1.14 \mathrm{mg} / \mathrm{kg})$ of $\mathrm{Fe}$ occurred in peas (De Monte) while the lowest concentration $(0.75 \pm 0.19 \mathrm{mg} / \mathrm{kg})$ occurred in Tomatoes (Lena). The highest mean concentration $(0.35 \pm 0.48 \mathrm{mg} / \mathrm{kg})$ of $\mathrm{Pb}$ occurred in baked beans (White Pearl) while the lowest mean concentration $(0.04 \pm 0.01 \mathrm{mg} / \mathrm{kg})$ occurred in green beans (Green Giant).

Specifically, mean concentrations of $\mathrm{Fe}$ across individual canned food samples $(\mathrm{mg} / \mathrm{Kg})$ ranged from $2.57 \pm 1.94$ to $10.46 \pm 0.59$, 
$2.19 \pm 0.65$ to $6.23 \pm 1.10,0.75 \pm 0.19$ to $11.01 \pm 5.38,11.13 \pm 0.52$ to $14.36 \pm 0.26$, $15.15 \pm 1.67$ to $18.40 \pm 0.37$ and $9.80 \pm 1.51$ to $20.57 \pm 1.14$ in Fish, Baked beans, Tomatoes, Carrots, Green beans and Peas respectively. Similarly, $\mathrm{Zn}$ ranged from $0.18 \pm 0.11$ to $0.39 \pm 0.03,0.41 \pm 0.03$ to $0.93 \pm 0.21,0.81 \pm 0.70$ to $1.47 \pm 0.20,1.68 \pm 0.16$ to $2.73 \pm 0.69$, $1.74 \pm 0.16$ to $4.17 \pm 0.69,1.11 \pm 0.10$ to $3.18 \pm 1.32$. Values for $\mathrm{Cd}$ ranged from $0.01 \pm 0.00$ to $0.01 \pm 0.00,0.04 \pm 0.01$ to $0.05 \pm 0.01,0.04 \pm 0.01$ to $0.07 \pm 0.01,0.02 \pm 0.00$ to $0.21 \pm 0.23,0.02 \pm 0.02$ to $0.09 \pm 0.01$, $0.03 \pm 0.00$ to $0.11 \pm 0.02$. The concentration of $\mathrm{Cu}$ across food sample ranged as follows; $0.19 \pm 0.24$ to $2.27 \pm 0.35,1.94 \pm 0.34$ to $1.97 \pm 0.84,1.93 \pm 0.57$ to $2.89 \pm 0.06,2.30 \pm 0.21$ to $2.33 \pm 0.18,1.63 \pm 1.11$ to $4.34 \pm 0.27$, $1.88 \pm 0.20$ to $4.87 \pm 0.42$. $\mathrm{Pb}$ had values $0.06 \pm 0.48$ to $0.07 \pm 0.00,0.06 \pm 0.01$ to $0.35 \pm 0.48,0.08 \pm 0.05$ to $0.17 \pm 0.21,0.04 \pm 0.00$ to $0.06 \pm 0.01,0.04 \pm 0.01$ to $0.06 \pm 0.01$, $0.05 \pm 0.01$ to $0.32 \pm 0.36$ in Fish, Baked beans, Tomatoes, Carrots, Green beans and Peas respectively.

The results showed significant difference $(\mathrm{p}<0.05)$ in the values of $\mathrm{Cu}$ and $\mathrm{Fe}$ and a highly significant difference $(\mathrm{p}<0.001)$ in $\mathrm{Cd}$ in the different brands of canned fish sample. There was no significant difference in the values of $\mathrm{Pb}$ in canned fish for this study and was found lower than 0.202 and $0.114 \mathrm{mg} / \mathrm{kg}$ and $0.12 \pm 0.34$ to $1.87 \pm 0.47 \mathrm{mg} / \mathrm{kg}$ as reported by Russo et al., 2013 and Erhunmwunse and Tongo 2018 respectively. Cd concentrations were above the the allowable limits for metals by FAO/WHO (1993) $(0.10 \mu \mathrm{g} / \mathrm{g})$. The levels obtained in this study fall below $0.0-0.23$ $\mathrm{mg} / \mathrm{kg}$ as reported by Al-Maylay and Hussein (2014). Iron $\mathrm{Fe}$ is regarded as an essential element for both humans and other organisms metabolic balance and do cause any form of nutritional loss in (Mol, 2011). It is incorporated into haem complex which is essential for cytochrome proteins facilitating redox reaction and oxygen carrier proteins such as hemoglobin and methemoglobin. However, high concentration of $\mathrm{Fe}$ in body tissues must be highly monitored because in excessive amounts, it can lead to tissue damage (Abbaspour et al., 2014).

Fathabad et al., (2015) reported iron and lead, in canned fish sold in Tehran above the acceptable limits. The sampled food in this study showed the level of Fe to be relatively high in all the classes especially in Green Giant and De Monte peas). The values for Fe across the different classes of food either showed a significant and highly significant values $(p<$ $0.05-p<0.001)$. The levels of $\mathrm{Fe}$ in fish samples in this study was also relatively lower than the research carried out by Al-Mutarri, (2015), with high concentration of Fe (57.41 ppm-101.55 ppm) in canned tuna fish, in Hilla City Iraq. It is pertinent to note that prolong exposure to the essential element may change several sensory properties of the food (Al-Mutarri, 2015). The recommended dietary allowance value for $\mathrm{Fe}$ for each person is in the range of $10-18 \mathrm{mg} /$ day (Demirezen and Uruc, 2006). Internal erosion as a result of over storage can also be a factor increasing the concentration of iron (Dantas et al., 2008; AlMutarri, 2015).

The presence of $\mathrm{Cu}$ in the body system helps in the removal of free radicals preventing cell structure damage. $\mathrm{Zn}$ on the other hand, functions as a cofactor for many enzymes of the body. However, prolonged exposure can cause poisoning, diarrhea and fever (Chi et al., 2007). $\mathrm{Zn}$ and $\mathrm{Cu}$ had lowest concentration of $0.03 \pm 0.00 \mathrm{mg} / \mathrm{Kg}$ for Trio peas and the highest value $4.34 \pm 0.27 \mathrm{mg} / \mathrm{Kg}$. Salama and Radwan (2005) reported higher values (2.839 to 8.012 and 6.111 to $15.861 \mathrm{mg} / \mathrm{kg}$ ) for $\mathrm{Cu}$ and $\mathrm{Zn}$ but were also below the allowable limits (CAC, 1993; USDA, 2003).

In this study, $\mathrm{Pb}$ values were lowest $(0.04 \pm 0.00 \mathrm{mg} / \mathrm{kg})$ in green giant carrotwhile the highest level $(0.35 \pm 0.48)$ was in white pearl baked beans. Atake (2016) reported values ranging from 0.021 and $0.045(\mu \mathrm{g} / \mathrm{ml})$ for $\mathrm{Pb}$ in canned beer but were found to be below the permissible limit for alcoholic beverage $(0.5$ $\mathrm{mg} / \mathrm{L})$, but exceeded the allowable limit for $\mathrm{Pb}$ in drinking water (Biurrum et al., 1991). The presence of $\mathrm{Pb}$ in food diet arises as a function of environmental emissions for example mining. In Zamfara State, Northern Nigeria, Over 400 children died as a result of $\mathrm{Pb}$ intake from artisanal mining activities. $\mathrm{Pb}$ leads to decrease in learning capacities, anaemia and death in children. 


\section{Conclusion}

In this study, $\mathrm{Fe}$ was found to be prevalent in all classes of food tested with values as high as $20.57 \pm 1.14 \mathrm{mg} / 1$ in Del Monte Peas. High concentrations of $\mathrm{Fe}$ in body tissues must be highly monitored because in excessive amounts, it can result in tissue damage. Other metals were below recommended values. Facility modernization and quality manufacturing and packaging is required to prevent heavy metal contamination in canned food products and thus reduce possible health hazards to consumers in Nigeria. A regular monitoring of canned foods available to the public is recommended to safeguard public health especially when recommended levels are exceeded.

\section{References}

Abbaspour, N., Hurrell, R., Kelishadi, R. (2014). Review on iron and its importance for human health. J. Res. Med Sciences, 19(2):164-174.

Al-Mutarri, A.K. (2015). Estimation of some heavy metals in canned tuna fish found in local markets of Hilla City, Iraq. Mesopotamian Environmental Journal $1(3): 26-30$.

Atake, N.F. (2016). Determination of heavy metal concentration in canned beer and its effect on human health in Owerri, Nigeria. African Journal of Chemistry 3(2): $163-168$.

Biurrum, M.C.Y., Dopazo, M.C.G., Barrera, M.P.B., Barrera, A.B. (1991). Determination de ploma en cerveza por espectometria de absorption atomica con atomizacion electrotermica. Alimentaria, 223: 59-62.

Blunden, S., Wallace, T. (2003). Tin in canned food: a review and understanding of occurrence and effect. Food and Chemical Toxicology, 41: 1651-1662.

Chi, Q.Q., Zhu, G.W and Alan, L. (2007). Bioaccumulation of heavy metals in fishes from Taihu Lake, China. Journal Environ. Sci. (Beijing, China) 19:1500 1504.

FAO/WHO (Codex Alimentarius Commission, CAC). 1993. Joint FAO/WHO Food Standards Program, p. 391.

Dantas, F. B., Dantas S. T., Saron, E. S., Vaz de Faria, E and Kiyataka, P. H. (2008).
Evaluation of DRD cans for tuna fish packaging. Brazilian Journal of Food Technology 11(3): 234-240.

Dehelean, A. and Magdas, D. A. (2013). Analysis of mineral and heavy metal content of some commercial fruit juices by inductively coupled plasma mass spectrometry. The Scientific World Journal.

Demiriezen D, Uruc K (2006). Comparative study of trace elements in certain fish, meat and meat products. Meat Science, 74:255-260.

Ebadi., F.A., Shariatifar., N., Ehsani, A., Sayadi, M. (2015). Evaluation of toxic metals in canned fish market in Tehran. International Journal of Pharma Sciences and Research. 6(5):818-822.

Erhunmwunse, N.O. and Tongo, I. (2018). Health Risk Assessment of Selected Trace Elements in Canned Fish Sold in Benin City, Edo State, Nigeria. Nigerian Research Journal of Engineering and Environmental Sciences 3(1) 229-235.

Ghasemidehkordi, B., Malekirad, A. A., Nazem, H., Fazilati, M., Salavati, H., Shariatifar, N., Rezaei, M., Khaneghah, A. M., Fakhri, Y. (2018). Concentration of lead and mercury in collected vegetables and herbs from Markazi province, Iran: Non-carcinogenic risk assessment. Food and Chemical Toxicology.

Khalafalla, F. A., Ali, F. H., Hassan, A.R.H and Basta, S.E. (2016). Residues of lead, cadmium, mercury and tin in canned meat products from Egypt: an emphasis on permissible limits and sources of contamination. Journal für Verbraucherschutz und Lebensmittelsicherheit, 11: 137-143.

Kocak, S., Tokusoglu, O., Aycan, S. (2005). Some heavy metal and trace essential element detection in canned vegetable foodstuffs by differential pulse polarography (DPP). Electronic Journal Environ Agric Food Chem 4: 871-878.

Likuku, A.S., Mmolawa, K.B., Gaboutloeloe, G.K. (2013). Assessment of heavy metal enrichment and degree of contamination around copper-nickel mine in the Selebi Phikwe Region, Eastern Botswana. Environment and Ecology Research, $1(2): 32-40$. 
Maduabuchi, J.-M., Adigba, E., Nzegwu, C., Oragwu, C., Okonkwo, I and Orisakwe, O. E. (2007). Arsenic and chromium in canned and non-canned beverages in Nigeria: a potential public health concern. International Journal of Environmental Research and Public Health 4: 28-33.

Makki, F. M., Ziarati, P. (2014). Determination of histamine and heavy metal concentrations in tomato pastes and fresh tomato (Solanum lycopersicum) in Iran. Biosci Biotechnol Res Asia, 11: 537-544.

Mani, M., Srinivasan, B., Kalyanasundram, I., Muthukumarasamy, S. (2012). Characteristics levels of heavy metals in canned tuna fish. Journal of Toxicology and Environmental Health Sciences. 4 (2): $43-45$.

Massadeh, A.M., Al-Massaedh A.A.T., Kharibeh, S. (2017). Determination of selected elements in canned food sold in Jordan markets. Environ. Sci. Pollut. Res. https://doi.org/10.1007/s11356017-0465-5.

Mashhadizadeh, M. H., Amoli-Diva, M., Shapouri, M. R and Afruzi, H. (2014). Solid phase extraction of trace amounts of silver, cadmium, copper, mercury, and lead in various food samples based on ethylene glycol bis-mercaptoacetate modified 3-(trimethoxysilyl)-1propanethiol coated Fe $3 \mathrm{O} 4$ nanoparticles. Food chemistry, 300-305.

Mol, S. (2011) Levels of Selected trace metals in canned tuna fish produced in turkey. Journal of Food Composition and Analysis, 24(1): 66-69.

Prashanth, L., Kattapagari, K. K., Chitturi, R. T., Baddam, V. R. R., Prasad, L. K. (2015).
A review on role of essential trace elements in health and disease. Journal of $\mathrm{Dr}$ NTR University of Health Sciences, 4: 75.

Rather, I.A., Koh, W.Y., Paek, W.K., Lim, J. (2017). The Sources of Chemical Contaminants in Food and Their Health Implications. Frontiers in Phamarcology, 8:830.

Radojevic, M. and Bashkin, V. N. (1999). Practical Environmental Analysis. 2nd edition, RSC Publishing UK, p. 457.

Russo, R., Lo Voi, A., De Simone, A., Serpe, F. P., Anastasio, A., Pepe, T., Cacace, D., Severino, L. (2013). Heavy Metals in Canned Tuna from Italian Markets, Journal of Food Protection, 76(2) 355 359.

Salama, A., Radwan, M. A. (2005). Heavy metals $(\mathrm{Cd}, \mathrm{Pb})$ and trace elements $(\mathrm{Cu}$, $\mathrm{Zn}$ ) contents in some foodstuffs from the Egyptian market. Emir. J. Agric. Sci. 17 (1):34-42.

Salma, I., Sajib, M., Motalab, M., Mumtaz, B., Jahan, S., Hoque, M., Saha, B. (2015) Comparative Evaluation of Macro and Micro-Nutrient Element and Heavy Metal Contents of Commercial Fruit Juices Available in Bangladesh. American Journal of Food and Nutrition, 3: 56-63.

Savić, S. R., Petrović, S. M., Stamenković, J. J., Petronijević, Ž. B. (2015). The presence of minerals in clear orange juices. Advanced Technologies 4: 71-78.

USDA (2003). Zinc in foods-draft for comments. Foreign Agricultural Service (GAIN Report) CH3043 China, Peoples Republic of FAIRS, products specific MRL. p1 and 2. 